\title{
Incorporation of endogenous urea nitrogen into the amino acids of bacterial protein in the rumen of goats fed diets with various protein levels
}

\author{
J.P. Michalski ${ }^{1}$, J. Kowalczyk, M. Czauderna and W. Litwin \\ The Kielanowski Institute of Animal Physiology and Nutrition, Polish Academy of Sciences \\ 05-110 Jabłonna, Poland
}

KEY WORDS: endogenous urea, ${ }^{15} \mathrm{~N}$, rumen bacteria, protein level, dairy goats

Received: 13 August .2013

Revised: 6 September 2013

Accepted: 22 September 2013

${ }^{1}$ Corresponding author: e-mail: j.p.michalski@op.pl

\begin{abstract}
The aim of the study was to investigate the effect of different levels of protein in a diet on the incorporation of endogenous urea nitrogen (EUN) into individual amino acids (AA) of the ruminal bacteria of goats fed a low- (LP), medium- (MP), or high-protein diet (HP) in a $3 \times 3$ Latin square design. Three Alpine goats of about $35 \mathrm{~kg}$ body weight fitted with cannula into the rumen and catheter into the jugular vein were fed three isoenergetic diets containing $11 \%(\mathrm{LP}), 13 \%(\mathrm{MP})$, or $16 \%$ (HP) crude protein in dry matter. The goats were infused for 6 days continuously with an ${ }^{15} \mathrm{~N}$ urea solution into the jugular vein. Ruminal bacteria were hydrolysed with $6 \mathrm{M} \mathrm{HCl}$. Next, butyl derivatives of free bacterial $\mathrm{AA}$ were obtained using $\mathrm{HCl}$ in butanol, then $\mathrm{N}$-acylated using trifluoroacetic acid anhydride and analysed by gas chromatography using a mass-selective detector. The concentration of urea in plasma was 178, 356 and $667 \mathrm{mg} \cdot \mathrm{I}^{-1}$ in goats from groups LP, MP and HP, respectively. ${ }^{15} \mathrm{~N}$-excess during the infusion of labelled urea was significantly higher $(P<0.05)$ in the vast majority of $A A$ of ruminal bacteria from goats fed the LP diet in comparison with goats fed the HP diet. Therefore, the level of protein in the diets affects the incorporation of EUN into bacterial AA. With the LP diet, EUN was incorporated mostly into glutamic acid, isoleucine and arginine, while in the case of the HP diet, into glutamic acid and arginine, as well as methionine. Regardless of the level of nitrogen in the diets, the incorporation of ${ }^{15} \mathrm{~N}$ into proline was very low. Irrespective of the dietary nitrogen level, EUN appears to be predominantly used for synthesis of glutamic acid in ruminal bacteria.
\end{abstract}

\section{Introduction}

In ruminants, significant amounts of urea formed in the liver can be transferred to the rumen (Kowalczyk et al., 1975a,b; Harmeyer and Martens, 1980; Kennedy and Milligan, 1980). Urea is then hydrolysed in the rumen (Gibbons and McKarthy, 1957 ) and the resulting ammonia is utilized by rumen bacteria as an important source of nitrogen for protein synthesis (Gärtner et al., 1961; Virtanen, 1964; Bunting et al., 1989). The amount of endogenous nitrogen utilized for the synthesis of bacterial protein can exceed half of the amount of nitrogen consumed in the ration, in case of insufficient supply of nitrogen in the diets (Kowalczyk et al., 1975a,b). This nitrogen is incorporated at various proportions into different amino acids of bacterial proteins and the proportions depend on the type of 
rumen fermentation and results from diets (Havassy et al., 1982).

It was shown in our previous work that increasing the protein content in the diet of goats reduced the efficiency of utilizing endogenous urea nitrogen (Michalski et al., 2012). The hypothesis for the study was that the endogenous urea nitrogen of blood can be utilized by ruminal bacteria for biosynthesis of amino acids, and that the extent of this utilization depends on the protein level in diets.

The aim of the current study was to estimate the size of endogenous urea nitrogen incorporation into individual amino acids of ruminal bacterial protein in goats fed a diet containing a low, medium, or high protein level.

\section{Material and methods}

\section{Animals and nutrition}

The experiment was carried out on three primiparous Alpine goats at 105 days of lactation. The experimental design was a $3 \times 3$ Latin square. The goats were fitted with a rumen cannula and permanent catheter into the jugular vein. Lactating goats were 12 months old and weighed $35 \pm 2 \mathrm{~kg}$. They were housed in individual cages and fed every $6 \mathrm{~h}$ with one of three isoenergetic diets containing, respectively, low (LP), medium (MP), or high (HP) protein levels. The protein concentrations were $11 \%, 13 \%$ and $16 \%$ in DM, respectively. The diet containing the medium level of protein best meets the norms of NRC (1981). The daily amount of the diet (1200 g hay and $1000 \mathrm{~g}$ concentrate), was divided into 4 portions (4 $\times 550 \mathrm{~g})$. Water was freely available. Ingredients of the concentrate are given in Table 1 and the nutrient contents are given in Table 2.

Table 1. Ingredients of the concentrate, $\%$

\begin{tabular}{llll}
\hline \multirow{2}{*}{ Ingredient } & \multicolumn{3}{l}{ Protein level in diets } \\
\cline { 2 - 4 } & low & medium & high \\
\hline Barley grain & 11.56 & 11.51 & 11.63 \\
Dried beet pulp & 40.13 & 40.03 & 40.44 \\
Wheat starch & 35.88 & 28.81 & 13.55 \\
Soyabean meal & 10.43 & 17.65 & 32.36 \\
Mineral-vitamin mix & 2.01 & 2.00 & 2.02 \\
\hline 'Polfamix OK (BASF) & & &
\end{tabular}

Table 2. The nutrient content of feeds, $\%$ in dry matter

\begin{tabular}{lrrrr}
\hline & \multirow{4}{*}{ Hay } & \multicolumn{3}{l}{ Concentrate } \\
\cline { 3 - 5 } Indices & & \multicolumn{1}{l}{ low } & medium & \multicolumn{1}{l}{ high } \\
\hline Dry matter & 91.53 & 89.21 & 89.68 & 89.68 \\
Crude protein & 11.27 & 11.07 & 15.05 & 21.60 \\
Ether extract & 2.15 & 0.95 & 1.65 & 2.21 \\
Crude fibre & 30.66 & 8.51 & 8.40 & 8.08 \\
Ash & 5.95 & 4.24 & 4.72 & 5.54 \\
ME, MJ $\cdot \mathrm{kg}^{-1}$ & 10.55 & 12.58 & 12.56 & 12.44 \\
\hline
\end{tabular}

\section{Experimental design and sampling}

The 21-day experimental period consisted of 15 days of adaptation to the diets and 6 days for urea infusion. After the adaptation period, samples of feeds, rumen liquid and blood were collected for analyses. Ruminal liquid $(200 \mathrm{ml})$ and blood samples from the jugular vein $(10 \mathrm{ml})$ were collected twice a day at 08.00 and 14.00. Ruminal bacteria were isolated from ruminal liquid by two-step centrifugation, according to Meyer et al. (1967). All collected samples were stored at $-20^{\circ} \mathrm{C}$ until analysis. Ruminal bacteria were lyophilised.

\section{${ }^{15} \mathrm{~N}$-urea infusion}

From the second day of sample collection, goats were continuously infused for 6 days with ${ }^{15} \mathrm{~N}$-labelled urea (98 atom \% excess). All of the animals were infused into the jugular vein with $1.6 \mathrm{~g} \cdot \mathrm{d}^{-1}$ ${ }^{15} \mathrm{~N}$-urea, dissolved in $600 \mathrm{ml}$ of $0.9 \% \mathrm{NaCl}$ solution. The amount of ${ }^{15} \mathrm{~N}$ administered was approximately $5 \mathrm{mg}{ }^{15} \mathrm{~N} \cdot \mathrm{kg}^{-1}$ body weight per day.

\section{Analyses}

The nutrient contents in feeds was determined according to AOAC procedures (1990). Ammonia in ruminal liquid was determined by the Conway method (1954). The concentrations of urea in ruminal liquid samples were quantified using high-performance liquid chromatography with pre-column derivation (Czauderna and Kowalczyk, 2009).

The bacterial protein was hydrolysed in culture tubes, using $6 \mathrm{M} \mathrm{HCl}$ in water at $105^{\circ} \mathrm{C}$ for $22 \mathrm{~h}$. Then the samples were dried with a rotary evaporator at $60^{\circ} \mathrm{C}$. Free amino acids were esterified in culture tubes with $3 \mathrm{M}$ hydrochloride in n-butanol (Sigma-Aldrich) $\left(35 \mathrm{~min}\right.$. at $\left.100^{\circ} \mathrm{C}\right)$. The aminoacid n-butyl esters were then $\mathrm{N}$-acylated with trifluoroacetic acid anhydride $\left(5 \mathrm{~min}\right.$. at $\left.130^{\circ} \mathrm{C}\right)$ according to Gehrke (2005). N- trifluoroacetyl n-butyl esters of amino acids were analysed by gas chromatography with a mass-selective detector using a capillary column $(30 \mathrm{~m} \times 0.25 \mathrm{~mm} \times 0.25 \mu \mathrm{m})$. Glutamine and glutamic acid, as well as asparagine and aspartic acid, were determined together as Nacylated butyl derivatives of glutamic and aspartic acids. The content of isotope ${ }^{15} \mathrm{~N}$ in individual amino acids was calculated by reading the intensity of individual ions with a mass detector.

The data were statistically analysed using the non-parametric Mann-Whitney U test for comparing independent experimental groups. The Statistica v. 10 package was used (www.statsoft.pl). 


\section{Results and discussion}

No significant differences in diet intake were found among all groups of goats (Table 3 ).

The content of ammonia in ruminal liquid (Table 4) differed highly significantly among groups. The amount of ruminal ammonia was larger in the group with the medium protein level and highest in the group with the high protein level (by $81 \%$ and $236 \%$, respectively). This indicates that the level of protein in the diet significantly affected the concentration of ammonia nitrogen in ruminal liquid, pointing to greater protein degradation in the rumen. Increasing protein intake caused a significant increase in the level of urea in blood plasma. Plasma urea concentration differed highly significantly among groups $(P<0.01)$, and increased together with the level of protein in the diets (Table 4). At the medium level of protein, it was increased by $100 \%$, and at the high level, by $275 \%$. These changes in rumen fluid ammonia or blood urea are typical in ruminants fed diets with different levels of protein (Lapierre and Lobley, 2001).

The amino acid concentrations as well as the profile of amino acids in bacteria protein (Table 5) were similar to the findings of Michałowski (1990). We noted that the amino acid profile of bacterial proteins does not depend on the protein content of the diet. There were, however, statistically significant differences in the content of individual amino acids in the bacterial mass, depending on the protein content of the diets. The increase in the dietary protein content resulted in a higher amino acid content in the bacterial mass due to a lower level of storage

Table 3. Diet intake, chemical composition, and metabolic energy of feed intake. Mean values $\pm \operatorname{SD}(n=9)$

\begin{tabular}{lcrr}
\hline \multirow{2}{*}{ Indices } & \multicolumn{3}{l}{ Protein level in diets } \\
\cline { 2 - 4 } & \multicolumn{1}{l}{ low } & \multicolumn{1}{l}{ medium } & \multicolumn{1}{l}{ high } \\
\hline Diet intake, $\mathrm{g} \cdot \mathrm{d}^{-1}$ & $1654 \pm 196$ & $1644 \pm 226$ & $1782 \pm 127$ \\
Crude protein, \% DM & $11.49^{\mathrm{a}} \pm 0.41$ & $13.27^{\mathrm{a}} \pm 0.24$ & $17.18^{\mathrm{c}} \pm 0.42$ \\
Ether extract, \% DM & $1.64^{\mathrm{a}} \pm 0.08$ & $2.02^{\mathrm{b}} \pm 0.14$ & $2.31^{\mathrm{c}} \pm 0.08$ \\
Crude fibre, \% DM & $15.53 \pm 2.24$ & $17.35 \pm 0.24$ & $16.84 \pm 1.02$ \\
Ash, \% DM & $5.24 \pm 0.27$ & $5.26 \pm 0.33$ & $5.77 \pm 0.19$ \\
ME, MJ $\cdot \mathrm{kg}^{-1} \mathrm{DM}$ & $11.92 \pm .18$ & $11.78 \pm 0.02$ & $11.73 \pm 0.08$ \\
\hline
\end{tabular}

values within a row with different letters differ significantly, a,b $(P<0.05)$, A,B $(P<0.01)$

Table 4. The level of ammonia in rumen liquid and urea concentration in plasma. Mean values $\pm S D(n=9)$

\begin{tabular}{llll}
\hline \multirow{2}{*}{ Indices } & \multicolumn{3}{l}{ Protein level in diets } \\
\cline { 2 - 4 } & low & medium & high \\
\hline $\mathrm{NH}_{3}$ in rumen liquid, $\mathrm{mg} \cdot \mathrm{l}^{-1}$ & $35.0^{\mathrm{a}} \pm 8.41$ & $74.8^{\mathrm{b}} \pm 45.0$ & $154.0^{\mathrm{c}} \pm 37.5$ \\
Plasma urea, $\mathrm{mg} \cdot \mathrm{l}^{-1}$ & $178^{\mathrm{a}} \pm 64$ & $356^{\mathrm{b}} \pm 161$ & $667^{\mathrm{c}} \pm 251$ \\
\hline Values within a row with different letters differ significantly, ${ }^{\mathrm{a}, \mathrm{b}}(P<0.05)$, \\
$\mathrm{A}, \mathrm{B}(P<0.01)$
\end{tabular}

Table 5. Mean concentrations of amino acids in lyophilized ruminal bacteria, $\mathrm{mg} \cdot 100 \mathrm{mg}^{-1}$

\begin{tabular}{llll}
\hline \multirow{2}{*}{ Amino acids } & \multicolumn{3}{l}{ Protein level in diets } \\
\cline { 2 - 4 } & low & medium & high \\
\hline Alanine (Ala) & $3.00^{\mathrm{A}}$ & $3.49^{\mathrm{B}}$ & $3.69^{\mathrm{B}}$ \\
Glycine (Gly) & $2.26^{\mathrm{A}}$ & $2.61^{\mathrm{Ba}}$ & $2.80^{\mathrm{Bb}}$ \\
Threonine (Thr) & $2.26^{\mathrm{A}}$ & $2.72^{\mathrm{B}}$ & $2.91^{\mathrm{B}}$ \\
Serine (Ser) & $1.98^{\mathrm{A}}$ & $2.31^{\mathrm{Ba}}$ & $2.47^{\mathrm{Bb}}$ \\
Valine (Val) & $2.08^{\mathrm{A}}$ & $2.48^{\mathrm{B}}$ & $2.61^{\mathrm{B}}$ \\
Leucine (Leu) & $3.02^{\mathrm{A}}$ & $3.51^{\mathrm{Ba}}$ & $3.74^{\mathrm{Bb}}$ \\
Isoleucine (Ile) & $1.81^{\mathrm{A}}$ & $2.14^{\mathrm{Ba}}$ & $2.32^{\mathrm{Bb}}$ \\
Proline (Pro) & $1.52^{\mathrm{A}}$ & $1.71^{\mathrm{B}}$ & $1.80^{\mathrm{B}}$ \\
Methionine (Met) & $0.81^{\mathrm{A}}$ & $1.00^{\mathrm{B}}$ & $1.07^{\mathrm{B}}$ \\
Aspartic acid (Asp) & $5.06^{\mathrm{A}}$ & $6.01^{\mathrm{B}}$ & $6.44^{\mathrm{B}}$ \\
Phenylalanine (Phe) & $1.93^{\mathrm{A}}$ & $2.24^{\mathrm{Ba}}$ & $2.42^{\mathrm{Bb}}$ \\
Glutamic acid (Glu) & $5.13^{\mathrm{A}}$ & $6.01^{\mathrm{B}}$ & $6.30^{\mathrm{B}}$ \\
Lysine (Lys) & $2.80^{\mathrm{A}}$ & $3.25^{\mathrm{B}}$ & $3.59^{\mathrm{B}}$ \\
\hline
\end{tabular}

values within a row with different letters differ significantly, a,b $(P<0.05)$, $\mathrm{A}, \mathrm{B}(P<0.01)$

compounds. Greater enrichment of bacterial amino acids with the ${ }^{15} \mathrm{~N}$ isotope was found in goats fed the low-protein diet than in goats fed the diets with medium and high levels of protein (Table 6). Considering the above, we argue that the greatest utilization of endogenous urea by ruminal microorganisms occurred in the goats fed the low-protein diet. Better utilization of urea could have resulted from greater recycling of urea to the rumen in this group (Kowalczyk et al., 1975a; Kennedy and Milligan, 1980; Brun-Bellut, 1996) and the lower supply of nitrogen from the feed. Better utilization of ammonia resulting from the recycled urea in goats fed the lowprotein diet may also have resulted from a higher content of wheat starch, which was the source of energy for microbial protein synthesis.

The observed differences in the recirculation resulted mainly from differences in the concentration of ammonia in the rumen in each dietary group, which are given in Table 4. This effect has been demonstrated in numerous studies by other authors (Gärtner et al., 1961; Rémond et al., 1996).

Labelled nitrogen $\left({ }^{15} \mathrm{~N}\right)$ was found in all assayed bacterial amino acids. At the low protein level in the diet, the greatest enrichment in the nitrogen isotope was observed in glutamic acid, isoleucine and arginine (Table 5). In the case of the high-protein diets, the greatest enrichment also was in glutamic acid, followed by arginine and methionine. The lowest incorporation of the infused ${ }^{15} \mathrm{~N}$ isotope, irrespective of the level of nitrogen in the diets, occurred in proline, without significant differences among dietary treatments. The protein level in the diets had the greatest impact on the enrichment in ${ }^{15} \mathrm{~N}$ of aspartic acid and phenylalanine. 
Table 6. ${ }^{15} \mathrm{~N}$ (at \% excess) in individual AA of bacterial protein after infusion of ${ }^{15} \mathrm{~N}$-labelled urea

\begin{tabular}{llll}
\hline \multirow{2}{*}{ Amino acids } & \multicolumn{3}{l}{ Protein level in diets } \\
\cline { 2 - 4 } & low & medium & high \\
\hline Alanine (Ala) & $1.05^{\mathrm{a}}$ & $0.71^{\mathrm{b}}$ & $0.26^{\mathrm{c}}$ \\
Glycine (Gly) & $1.49^{\mathrm{a}}$ & $1.09^{\mathrm{ab}}$ & $0.48^{\mathrm{b}}$ \\
Threonine (Thr) & $1.25^{\mathrm{a}}$ & $0.77^{\mathrm{a}}$ & $0.31^{\mathrm{b}}$ \\
Serine (Ser) & $1.25^{\mathrm{a}}$ & $0.84^{\mathrm{a}}$ & $0.29^{\mathrm{b}}$ \\
Valine (Val) & $1.52^{\mathrm{a}}$ & $1.00^{\mathrm{a}}$ & $0.31^{\mathrm{b}}$ \\
Leucine (Leu) & $1.56^{\mathrm{a}}$ & $1.06^{\mathrm{ab}}$ & $0.58^{\mathrm{b}}$ \\
Isoleucine (Ile) & $1.86^{\mathrm{a}}$ & $1.22^{\mathrm{ab}}$ & $0.58^{\mathrm{b}}$ \\
Proline (Pro) & 0.54 & 0.40 & 0.17 \\
Methionine (Met) & 1.52 & 1.36 & 0.63 \\
Arginine (Arg) & 1.82 & 0.88 & 0.69 \\
Aspartic acid (Asp) & $0.79^{\mathrm{a}}$ & $0.91^{\mathrm{ab}}$ & $0.04^{\mathrm{b}}$ \\
Phenylalanine (Phe) & $0.81^{\mathrm{a}}$ & $0.40^{\mathrm{ab}}$ & $0.12^{\mathrm{b}}$ \\
Glutamic acid ( Glu) & $2.76^{\mathrm{a}}$ & $1.83^{\mathrm{ab}}$ & $0.81^{\mathrm{b}}$ \\
Lysine (Lys) & $1.74^{\mathrm{a}}$ & $1.42^{\mathrm{ab}}$ & $0.57^{\mathrm{b}}$ \\
\hline values within a row with different letters differ significantly, ${ }^{\mathrm{a}, \mathrm{b}}(P<0.05)$
\end{tabular}

Glutamine and asparagine in the rumen act as ammonium transporters, a role involving the participation of the relevant enzymes transforming them into glutamic and aspartic acids. During hydrolysis of bacterial protein in an environment 6 $\mathrm{M} \mathrm{HCl}$, the $-\mathrm{NH}_{2}$ group is detached from the amino acid molecule (or more precisely, its amide group). The resulting $\mathrm{N}$-acyl butyl derivatives of glutamic acid or aspartic acid are, therefore, determined instead of glutamine and asparagine. Thus, the amount of the ${ }^{15} \mathrm{~N}$ isotope in the analysed amino acid reflects the actual contents of the ${ }^{15} \mathrm{~N}$ isotope in the residual molecule of amino acid, which was formed resulting from microbial biosynthesis. Therefore, a high enrichment in ${ }^{15} \mathrm{~N}$ of glutamic acid derivatives shows the greatest utilization of EUN for the synthesis of glutamine and glutamic acid. Also, in a study on growing sheep (Havassy et al., 1982), a high level of enrichment of glutamine was achieved, but only with high-fibre diets.

The level of enrichment of aspartic acid on the low- and medium-protein diets was similar to the results obtained by Havassy (1982) in sheep receiving roughage diets. The level of enrichment of lysine was high in the case of low- and medium-protein diets, but Havassy et al. (1982) in sheep given concentrates achieved much higher enrichment of lysine in ${ }^{15} \mathrm{~N}$. In our study, a high level of enrichment of methionine was found, much higher than in the study of Havassy et al. (1982). The lowest enrichment of proline indicates very low utilization of EUN in de novo bio-synthesis of this amino acid in the rumen.

The high enrichment of arginine in ${ }^{15} \mathrm{~N}$ may point to the high intensity of the urea cycle in ruminal bacteria. This amino acid is known to be formed in this cycle in which ammonia released

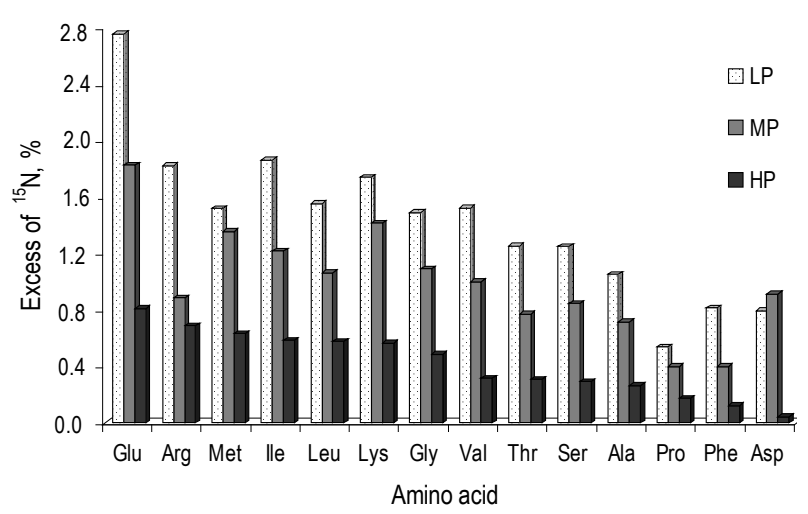

Figure 1. ${ }^{15} \mathrm{~N}$ (at\% excess) in individual AA of bacterial protein after infusion of ${ }^{15} \mathrm{~N}$ labeled urea

from urea is transported through aspartic acid and attached to citrulline to form the molecule, arginine.

The differences in the level of enrichment in isotope ${ }^{15} \mathrm{~N}$ between our experiment and the study of Havassy et al. (1982) could be ascribed to the different type and composition of the diets.

\section{Conclusions}

The level of protein in the diet affects the utilization of endogenous urea nitrogen by ruminal microorganisms for biosynthesis of bacterial amino acids. The most efficient utilization of endogenous urea nitrogen was found in goats consuming the diet with the low protein level and decreased with the increasing dietary protein level. Irrespective of the dietary nitrogen level, EUN was incorporated mostly into glutamic acid. Whatever the level of nitrogen in the diets, the incorporation of ${ }^{15} \mathrm{~N}$ into proline was very low.

The results of this study show that the incorporation of endogenous urea nitrogen into various amino acids of rumen bacteria in goats varies depending on the dietary level of protein.

\section{Acknowledgements}

This work was supported by the National Science Centre, Project No. N N311 517740.

\section{References}

AOAC, 1990. Association of Official Analytical Chemists, Official Methods of Analysis. $15^{\text {th }}$ Edition. Washington, DC

Brun-Bellut J., 1996. Urea recycling in the rumen of dairy goats: effects of physiological stage and composition of intake. Small Ruminant Res. 23, 83-90

Bunting L.D., Boling J.A., MacKown C.T., Davenport G.M., 1989. Effect of dietary protein level on nitrogen metabolism in the growing bovine: I Nitrogen recycling and intestinal protein supply in calves. J. Anim. Sci. 67, 820-826 
Conway E.J., 1954. Micro Diffusion Analysis and Volumetric Error. Crosby, Lockwood and Son Ltd. London

Czauderna M., Kowalczyk J., 2009. Easy and accurate determination of urea in milk, blood plasma, urine and selected diets of mammals by high-performance liquid chromatography with photodiode array detection preceded by pre-column derivatization. Chem. Anal. (Warsaw) 54, 919-937

Gärtner K., Decker P., Hill H., 1961. Untersuchungen über die Passage von Harnstoff und Ammoniak durch die Pansenwand von Ziege. Pflügers Arch. ges. Physiol. 274, 281-288

Gehrke C.W., 2005. Quantitation of Amino Acids by Gas-Liquid Chromatography. In: Ibolya Molnar-Perl (Editor). Quantitation of Amino Acids and Amines by Chromatography. Methods and Protocols. Elsevier. Journal of Chromatography Library, 70, 39-97

Gibbons R.J., McKarthy R.D., 1957. Obligatory anaerobic urea-hydrolyzing bacteria in the bovine rumen. Maryland Agric. Exp. Sta. Misc. Publ. 291, 12-16

Harmeyer J., Martens H., 1980. Aspects of urea metabolism in ruminants with reference to the goat. J. Dairy Sci. 63,1707-1728

Havassy I., Kowalczyk J., Horsky K., Košta K., Otwinowska A., 1982. Incorporation of $15 \mathrm{~N}$-urea into individual amino acids of rumen bacteria and blond plasma protein in sheep. Acta Physiol. Pol. 33, 415-419

Kennedy P.M., Milligan L.P., 1980. The degradation and utilization of endogenous urea in the gastrointestinal tract of ruminants: A review. Can. J. Anim. Sci. 60, 205-221

Kowalczyk J., Havassy I., Otwinowska A., Košt’a K., 1975a. Passage of intravenously administered $15 \mathrm{~N}$ urea into the digestive tract and its excretion in sheep. Acta Physiol. Pol. 26, 299-306
Kowalczyk J., Havassy l., Košta K., Otwinowska A., 1975b. Incorporation of intravenously administered $15 \mathrm{~N}$ labeled urea in to the bacterial protein in the sheep. Acta Physiol. Pol. 26, 307-312

Lapierre H., Lobley G.E., 2001. Nitrogen recycling in the ruminant: A Review. J. Dairy Sci. 84, Suppl. E, E223-E236

Meyer R.M., Bartley E.E., Deyoe C.W., Colenbrander V.F., 1967. Feed Processing. I. Ration effects on rumen microbial protein synthesis and amino acid composition. J. Dairy Sci. 50, 1327-1332

Michalski J.P., Kowalczyk J., Voigt J., Hammon H.M., Czauderna M., Metges C.C., 2012. Efficiency of endogenous urea ${ }^{15} \mathrm{~N}$ nitrogen incorporation into bacterial and milk protein of goats fed diets with three different protein levels. J. Anim. Feed Sci. 21, $599-612$

Michałowski T., 1990. The synthesis and turnower of the cellular matter of ciliates in the rumen. Acta Protozool. 29, 47-72

NRC, 1981. Nutrient Requirements of Domestic Animals. No. 15. Nutrient Requirements of Goats. National Academy Press. Washington, DC

Rémond D., Meschy F., Boivin R., 1996. Metabolites, water and mineral exchanges across the rumen wall: Mechanisms and regulation. Ann. Zootech. 45, 97-119

Virtanen A.I., 1964. Versuche über Milchproduktion ohne Protein unter ausschließlicher Verwendung von Harnstoff und Ammoniumstickstoff. Nachr. Gies. Hochsch.-Gesell. 33, 73-85 